\title{
Effect of inhaled frusemide on responses of airways to bradykinin and adenosine $5^{\prime}$-monophosphate in asthma
}

\author{
K Rajakulasingam, R Polosa, M K Church, P H Howarth, S T Holgate
}

\begin{abstract}
Background - Inhaled frusemide exerts a protective effect against bronchoconstriction induced by several indirect stimuli in asthma. This effect could be caused by interference with neural pathways. The effect of inhaled frusemide on bronchoconstriction induced by inhaled bradykinin, which is thought to cause bronchoconstriction via neural mechanisms, was studied and compared with the effects of adenosine $5^{\prime}$-monophosphate (AMP) which probably produces its airway effects by augmenting mast cell mediator release and interfering with neural pathways.
\end{abstract}

Methods - Patients first underwent AMP and bradykinin challenges. They were then studied in a randomised, placebo controlled, double blind fashion. Ten atopic asthmatic subjects, studied on four days, were pretreated with inhaled frusemide (40 mg) or placebo for 10 minutes, five minutes before challenge with increasing concentrations of nebulised AMP or bradykinin.

Results - On the open visit days the provocative concentrations required to reduce forced expiratory volume in one second $\left(F E V_{1}\right)$ by $20 \%$ from baseline $\left(P_{20}\right)$ for AMP and bradykinin were $16.23(1.42-67.16)$ and $2.75(0.81-6.6) \mathrm{mg} /$ ml. There was a significant correlation between baseline AMP and bradykinin $\mathbf{P C}_{20}$ values. For AMP the geometric mean $\mathbf{P C}_{20}$ values following pretreatment with inhaled frusemide and matched placebo were $80.97(9.97->400 \cdot 0)$ and 14.86 $(2 \cdot 6-104 \cdot 6) \mathrm{mg} / \mathrm{ml}$ respectively $(95 \% \mathrm{CI}$ 0.49 to 0.98 ). For bradykinin the geomet-

Immunopharmacolog Group, University of Southampton, University ric mean $\mathbf{P C}_{20}$ values following pretreatMedicine, Southampton ment with inhaled frusemide and Southampton SO9 4XY matched placebo were 13.22 (2.53->16.0) $\mathrm{K}$ Rajakulasingam and $2.52(0.45-5.61) \mathrm{mg} / \mathrm{ml}$ respectively R Polosa

M K Church

P H Howarth

$S$ T Holgate

Reprint requests to: Dr K Rajakulasingam, Department of Allergy and Immunology, National Heart and Lung Institute, Dovehouse Street, London SW3 6LY, UK.

Received 22 April 1993 Returned to authors 14 June 1993

1993 Revised version received

10 January 1994

Accepted for publication

Accepted for pub
(Thorax 1994;49:485-491)

The loop diuretic frusemide, when administered by inhalation, protects the asthmatic airways against various bronchoconstrictor stimuli such as allergen, ${ }^{1}$ ultrasonically nebulised distilled water, ${ }^{2}$ exercise, ${ }^{3}$ cold air ${ }^{4}$ sodium metabisulphite, ${ }^{5}$ and adenosine $5^{\prime}$ monophosphate (AMP). ${ }^{6}$ The mechanisms underlying the protective effects of this drug against these different forms of provocation in asthma are not understood. Based on structure-activity studies with other loop diuretics the protective efficacy of inhaled frusemide is thought not to involve the ATP-dependent $\mathrm{Na}^{+}-\mathrm{K}^{+}-\mathrm{Cl}$ cotransport. ${ }^{7}$ Other possibilities include the capacity of this drug to locally generate prostaglandin $\mathrm{E}_{2}\left(\mathrm{PGE}_{2}\right)$ with functional antagonistic effects, ${ }^{89}$ a suppressive action on airway mast cells, ${ }^{10}$ and inhibition of neural pathways. In support of an effect on airway nerves, frusemide has been shown to inhibit the cough response induced by low chloride aerosols, ${ }^{11}$ and both inhaled frusemide and bumetanide produce dose-dependent inhibition of the contractile response of airways smooth muscle induced by stimulation of cholinergic and non-cholinergic non-adrenergic nerves independent of cyclooxygenase production in guinea pigs. ${ }^{12}$

Bradykinin is produced by the action of kallikreins on high molecular weight kininogen. ${ }^{13}$ Inhaled bradykinin induces bronchoconstriction in a dose-dependent fashion in asthmatic subjects ${ }^{14}{ }^{15}$. In vivo structure-activity studies have suggested that bradykinin produces bronchoconstriction by stimulating $\beta_{2}$ receptors. ${ }^{14}$ Studies in guinea pigs indicate an important role for tachykinin release from sensory neurones as a major pathway mediating the constrictor effects of bradykinin in this species. ${ }^{16}$ Bradykinin-induced bronchoconstriction is partially blocked by inhaled ipratropium bromide, ${ }^{15}$ and Ichinose et al have shown that FK 224, a neurokinin 1 (NK1) antagonist, affords eight fold protection against bradykinin-induced bronchoconstriction in asthma. ${ }^{17}$ Furthermore, nedocromil sodium and disodium cromoglycate, two drugs known to interfere with sensory nerve fibre discharge, also afford protection against this mediator. ${ }^{18}$ On the other hand, both the selective histamine $\mathrm{H}_{1}$ receptor antagonist, terfenadine, and the potent inhibitor of cyclooxygenase, flurbiprofen, exert only minimal protective effects on bradykinin-induced bronchoconstriction in asthma. ${ }^{19}$ 
The effect of inhaled frusemide on bradykinin-induced bronchoconstriction has not been reported. In this study we have investigated the effect of inhaled frusemide against bronchoconstriction provoked by bradykinin and compared it with that of AMP which probably produces its airway effects by augmenting mast cell mediator release and excitation of neural pathways. We have also assessed the degree of protection afforded by frusemide against both stimuli as, if a similar degree of protection was found, this would support a common mechanism of action for this drug in the airways.

\section{Methods}

SUBJECTS

Ten asthmatic subjects (eight males) with a mean (SE) age $25.5(2.4)$ years participated in the study. All subjects were non-smokers with atopic asthma as judged by at least one weal $>3 \mathrm{~mm}$ on skin prick testing with Dermatophagoides pteronyssinus, house dust, mixed grass pollen, cat fur, and feathers (Bencard, Brentford, Middlesex, UK). Their baseline $\mathrm{FEV}_{1}$ was $>75 \%$ of predicted values and none were receiving oral corticosteroids or theophylline, but five were on low dose inhaled beclomethasone (table 1). Treatment with inhaled $\beta_{2}$ agonists was withdrawn at least eight hours before each visit to the laboratory, although subjects were allowed to continue inhaled corticosteroids as usual. Patients were not studied within four weeks of an upper respiratory tract infection or exacerbation of their asthma and all visits to the laboratory were carried out at the same time of day. The study was approved by the Southampton University and Hospitals ethical subcommittee and written informed consent was given by all subjects involved in the study.

\section{BRONCHIAL PROVOCATION TESTS}

Bronchial challenge with adenosine 5'-monophosphate and bradykinin

Adenosine 5'-monophosphate (AMP) (Sigma Chemical Co, St Louis, USA) was made up in $0.9 \%$ sodium chloride in a series of doubling concentrations ranging from 0.39 to $400 \mathrm{mg}$ / $\mathrm{ml}(4.48-1151.4 \mathrm{mmol} / \mathrm{l})$. Bradykinin triacetic acid (Nova Biochem, Nottingham, UK) was dissolved in phosphate buffered saline ( $\mathrm{pH} 7.4$ ) to produce a concentration range of $0.03-16 \mathrm{mg} / \mathrm{ml} \quad(0.028-15.09 \mathrm{mmol} / \mathrm{l})$. To

\section{Table 1 Characteristics of subjects}

\begin{tabular}{lllc}
\hline $\begin{array}{l}\text { Subject } \\
\text { no }\end{array}$ & $\begin{array}{l}\text { Age } \\
\text { (years) }\end{array}$ & $\begin{array}{l}P C_{20} \text { histamine } \\
(\mathrm{mg} / \mathrm{ml})\end{array}$ & $\begin{array}{l}\mathrm{FEV}, \\
(\% \text { predicted })\end{array}$ \\
\hline 1 & 18 & $0 \cdot 23$ & $96 \cdot 0$ \\
2 & 29 & $0 \cdot 5$ & $105 \cdot 0$ \\
3 & 23 & $0 \cdot 5$ & $86 \cdot 0$ \\
4 & 20 & $1 \cdot 0$ & $95 \cdot 0$ \\
5 & 23 & $0 \cdot 25$ & $98 \cdot 0$ \\
6 & 33 & $1 \cdot 3$ & $78 \cdot 0$ \\
7 & 18 & $2 \cdot 4$ & $82 \cdot 0$ \\
8 & 32 & $0 \cdot 44$ & $94 \cdot 0$ \\
9 & 38 & $0 \cdot 27$ & $105 \cdot 0$ \\
10 & 21 & $1 \cdot 2$ & $102 \cdot 0$ \\
Mean (SE) & $25 \cdot 5(2 \cdot 4)$ & $* 0 \cdot 60$ & $94 \cdot 1(3 \cdot 1)$ \\
\hline
\end{tabular}

\footnotetext{
* Geometric mean.
}

avoid loss of bradykinin through oxidation and adherence to plastic surfaces the stock solution was stored at $4^{\circ} \mathrm{C}$ before use and bronchoprovocation was performed within 30 minutes of preparing the dilutions. The solutions were administered as aerosols generated from a starting volume of $3 \mathrm{ml}$ in a Cirrus Mininebuliser (Intersurgical, Middlesex, UK) driven by compressed air at $8 \mathrm{l} / \mathrm{min}$. Under these conditions the nebuliser generates an aerosol with a mass median particle diameter of $4 \cdot 1 \mu \mathrm{m} .{ }^{20}$

Bronchial challenge was performed with a technique modified from that of Chai et al..$^{21}$ Measurements of FEV , were made using a dry wedge spirometer (Vitalograph, Buckinghamshire, UK). Before challenge, after 15 minutes rest, three baseline measurements of $\mathrm{FEV}_{1}$ were made at three minute intervals and the highest value recorded. Subjects then inhaled nebulised $0.9 \%$ sodium chloride (saline) taking five slow breaths from functional residual capacity (FRC) to full inspiration, and $\mathrm{FEV}_{1}$ measurements performed at one and three minutes, the higher value being recorded. If this value was $10 \%$ of the initial $\mathrm{FEV}_{1}$ then bronchial provocation with AMP or bradykinin was undertaken. Increasing concentrations of agonists were inhaled at five minute intervals until the $\mathrm{FEV}_{1}$ had fallen by $>20 \%$ of the post-diluent baseline value, or until the highest concentrations of agonist had been administered. The percentage fall in $\mathrm{FEV}_{1}$ from post-diluent baseline was plotted against the cumulative concentration of agonist administered, and the provocative concentration of agonist required to produce a $20 \%$ fall in $\mathrm{FEV}_{1}$ from the post-diluent baseline $\left(\mathrm{PC}_{20}\right.$ $\left.\mathrm{FEV}_{1}\right)$ derived by linear interpolation of the last two points.

STUDY DESIGN

The study was divided into two phases.

Phase 1

Subjects attended the laboratory on three separate occasions at least 72 hours apart to undertake concentration response studies with inhaled AMP, bradykinin, and histamine in the absence of any drug treatment in order to establish the baseline level of response.

\section{Phase 2}

Subjects attended the laboratory on four occasions, separated by at least 72 hours, to undertake concentration response studies with inhaled AMP and bradykinin after nebulised frusemide or matched nebulised vehicle placebo. These were administered in a double blind and random fashion. On each occasion, after 15 minutes rest, three baseline measurements of $F E V_{1}$ were recorded at intervals of three minutes. This was followed by inhalation of nebulised frusemide $(10 \mathrm{mg} / \mathrm{ml}, \mathrm{pH} 9$, osmolarity $289 \mathrm{mosmol} / \mathrm{kg}$ ) or matched placebo ( $\mathrm{pH} \mathrm{9,} \mathrm{osmolarity} 298 \mathrm{mosmol} / \mathrm{kg}$ ). The aerosol solutions were generated from a start- 
Table $2 \quad P_{20}$ values $(\mathrm{mg} / \mathrm{ml})$ for $A M P$ and bradykinin ( $B K$ )

\begin{tabular}{|c|c|c|c|c|c|c|}
\hline $\begin{array}{l}\text { Subject } \\
\text { no }\end{array}$ & $\begin{array}{l}\text { Baseline } \\
P C_{20} A M P\end{array}$ & $\begin{array}{l}\text { Post-placebo } \\
P_{20} A M P\end{array}$ & $\begin{array}{l}\text { Post-frusemide } \\
\text { PC }_{20} \text { AMP }\end{array}$ & $\begin{array}{l}\text { Baseline } \\
P C_{20} B K\end{array}$ & $\begin{array}{l}\text { Post-placebo } \\
P_{20} B K\end{array}$ & $\begin{array}{l}\text { Post-frusemide } \\
P C_{20} B K\end{array}$ \\
\hline $\begin{array}{l}1 \\
2 \\
3 \\
4 \\
5 \\
6 \\
7 \\
8 \\
9 \\
10 \\
\text { Geometric mean } \\
\text { (range) }\end{array}$ & $\begin{array}{l}43 \cdot 72 \\
12 \cdot 8 \\
22 \cdot 38 \\
11 \cdot 92 \\
18 \cdot 3 \\
17 \cdot 88 \\
13 \cdot 04 \\
20 \cdot 84 \\
1 \cdot 42 \\
67 \cdot 16 \\
16 \cdot 23 \\
(1 \cdot 42-67 \cdot 16)\end{array}$ & $\begin{array}{c}80 \cdot 5 \\
2 \cdot 66 \\
7 \cdot 11 \\
6 \cdot 11 \\
22 \cdot 25 \\
15 \cdot 55 \\
12 \cdot 02 \\
49 \cdot 75 \\
2 \cdot 6 \\
104 \cdot 6 \\
14 \cdot 86 \\
(2 \cdot 6-104 \cdot 6)\end{array}$ & $\begin{array}{c}>400 \cdot 0 \\
20 \cdot 69 \\
85 \cdot 1 \\
9 \cdot 97 \\
79 \cdot 31 \\
122 \cdot 38 \\
153 \cdot 26 \\
59 \cdot 8 \\
12 \cdot 12 \\
>400 \cdot 0 \\
80 \cdot 97 \\
(9 \cdot 97->400 \cdot 0)\end{array}$ & $\begin{array}{l}4 \cdot 4 \\
0 \cdot 81 \\
6 \cdot 6 \\
5 \cdot 85 \\
1 \cdot 9 \\
5 \cdot 58 \\
1 \cdot 47 \\
2 \cdot 01 \\
1 \cdot 08 \\
5 \cdot 41 \\
2 \cdot 75 \\
(0 \cdot 81-6 \cdot 6)\end{array}$ & $\begin{array}{l}2 \cdot 6 \\
0 \cdot 45 \\
3 \cdot 7 \\
3 \cdot 38 \\
2 \cdot 64 \\
4 \cdot 4 \\
0.63 \\
5 \cdot 61 \\
3 \cdot 63 \\
4 \cdot 78 \\
2 \cdot 52 \\
(0 \cdot 45-5 \cdot 61)\end{array}$ & $\begin{array}{c}6.8 \\
2.53 \\
11.98 \\
>16.0 \\
7.7 \\
>16.0 \\
>16.0 \\
7.42 \\
13.31 \\
>16.0 \\
13.22 \\
(2.53->16.0)\end{array}$ \\
\hline
\end{tabular}

ing volume of $4.0 \mathrm{ml}$ in a Cirrus mini-nebuliser driven by compressed air at $6 \mathrm{l} / \mathrm{min}$, and inhaled to dryness by deep tidal breathing over 10 minute time period. The same nebuliser was used for all studies on all subjects. The dose of frusemide delivered to the mouth was calculated by differential weighing and on four of the occasions amounted to $28 \cdot 0(2 \cdot 6) \mathrm{mg} / \mathrm{ml}$. Five minutes after inhaling the frusemide or placebo a concentration response study with one of the two agonists was performed as described before.

\section{DATA ANALYSIS}

For $\mathrm{FEV}_{1}$ the lowest of the values recorded with each inhaled concentration of agonist was used for analysis. Baseline $\mathrm{FEV}_{1}$ measurements before bronchial challenges were compared between study days by two way analysis of variance (ANOVA). $\mathrm{FEV}_{1}$ values prior to bronchial challenges before and after treatment were compared within each study day using the Student's $t$ test for paired data. The airways response to AMP and bradykinin at each agonist concentration was expressed as the percentage change in $F E V_{1}$ from the postdiluent baseline value. Values of $\mathrm{PC}_{20}$ bradykinin and AMP were logarithmically transformed and compared using the Student's $t$ test for paired data and the results expressed as $95 \%$ confidence interval (CI). If a $20 \%$ fall in $\mathrm{FEV}_{1}$ was not achieved by the maximum dose of agonist, the $\mathrm{PC}_{20}$ was estimated as the next doubling dose.

Concentration ratios for the protective effect of frusemide against bronchoprovocation with each agonist were calculated by dividing the $\mathrm{PC}_{20}$ value obtained after administration of active drug by that obtained after placebo. The relative potency of frusemide in protecting against bronchoconstriction induced by the two agonists was analysed by comparing the concentration ratios using the Wilcoxon's signed rank test. The relation between $\mathrm{PC}_{20}$ $\mathrm{AMP}$ and $\mathrm{PC}_{20}$ bradykinin values, and the respective $\mathrm{PC}_{20}$ concentration ratios after frusemide pretreatment, were investigated by least squares linear regression analysis and Spearman's rank correlation analysis respectively. A p value of $<0.05$ was accepted as the minimum level of statistical significance.

\section{Results}

Baseline values of $\mathrm{FEV}_{1}$ did not differ significantly between any of the six study days, the mean values being $3.68(0.2), 3.63(0.2), 3.58$ $(0 \cdot 19), 3.5(0.2), 3.6(0.18)$, and $3.61(0.24) 1$ for open AMP and bradykinin days, AMP-active frusemide and AMP-placebo frusemide days, and bradykinin-active frusemide and bradykinin-placebo frusemide treatment days, respectively. There were no significant differences in baseline values of $\mathrm{FEV}_{1}$ after placebo or frusemide between any of the study days.

All 10 subjects exhibited bronchial responsiveness to inhaled AMP and bradykinin, the geometric mean (range) concentrations required to produce a $20 \%$ decrease in $\mathrm{FEV}_{1}$ $\left(\mathrm{PC}_{20} \mathrm{FEV}_{1}\right)$ values being 16.23 (1.42-67.16) and $2.75(0.81-6.6) \mathrm{mg} / \mathrm{ml}$, respectively. On a molar basis AMP was therefore approximately $17.9(4.0-48.3)$ fold less potent than bradykinin in reducing $\mathrm{FEV}_{1}$. A significant correlation was observed between baseline $\mathrm{PC}_{20} \mathrm{AMP}$ and bradykinin values $(r=0.58, \mathrm{p}<0.05)$. However, there was no correlation between bronchial responsiveness to histamine and either AMP or bradykinin.

Inhaled frusemide had a significant protective effect against the fall in $\mathrm{FEV}_{1}$ produced by $\mathrm{AMP}$, the geometric mean (range) $\mathrm{PC}_{20}$ increasing from $14.86(2 \cdot 6-104 \cdot 6)$ after placebo to $80.97(9.97->400.0) \mathrm{mg} / \mathrm{ml}$ after frusemide (95\% CI 0.49 to 0.98 ) (fig 1 , table 2 ). The same dose of frusemide was also effective in protecting against bradykinin-induced bronchoconstriction, the geometric mean (range) $\mathrm{PC}_{20}$ increasing from $2.52(0.45-5 \cdot 61)$ $\mathrm{mg} / \mathrm{ml}$ after placebo to $13.22(2.53->16.0)$ $\mathrm{mg} / \mathrm{ml}$ following frusemide pretreatment (95\% CI 0.43 to 1.01 ) (fig 2, table 2). When expressed as concentration ratios frusemide afforded 5.45 fold ( $>2.5$ doubling dilution) and 5.24 fold ( $>2.5$ doubling dilution) protection of the airways against AMP and bradykinin respectively. A significant correlation existed for the capacity of frusemide to protect against bronchoconstriction provoked by AMP and by bradykinin ( $\left.\mathrm{p}=0.05, r_{\mathrm{s}}=0.51\right)$.

\section{Discussion}

This study confirms previous findings that inhaled bradykinin and AMP both caused dose-related bronchoconstriction in asthmatic subjects. ${ }^{61415}$ Within the group a significant correlation existed between the baseline $\mathrm{PC}_{20}$ values for AMP and bradykinin. We have also shown that frusemide administered in an inhaled dose of about $28 \mathrm{mg}$ (of which about $10 \%$ reaches the airways) produced an approx- 

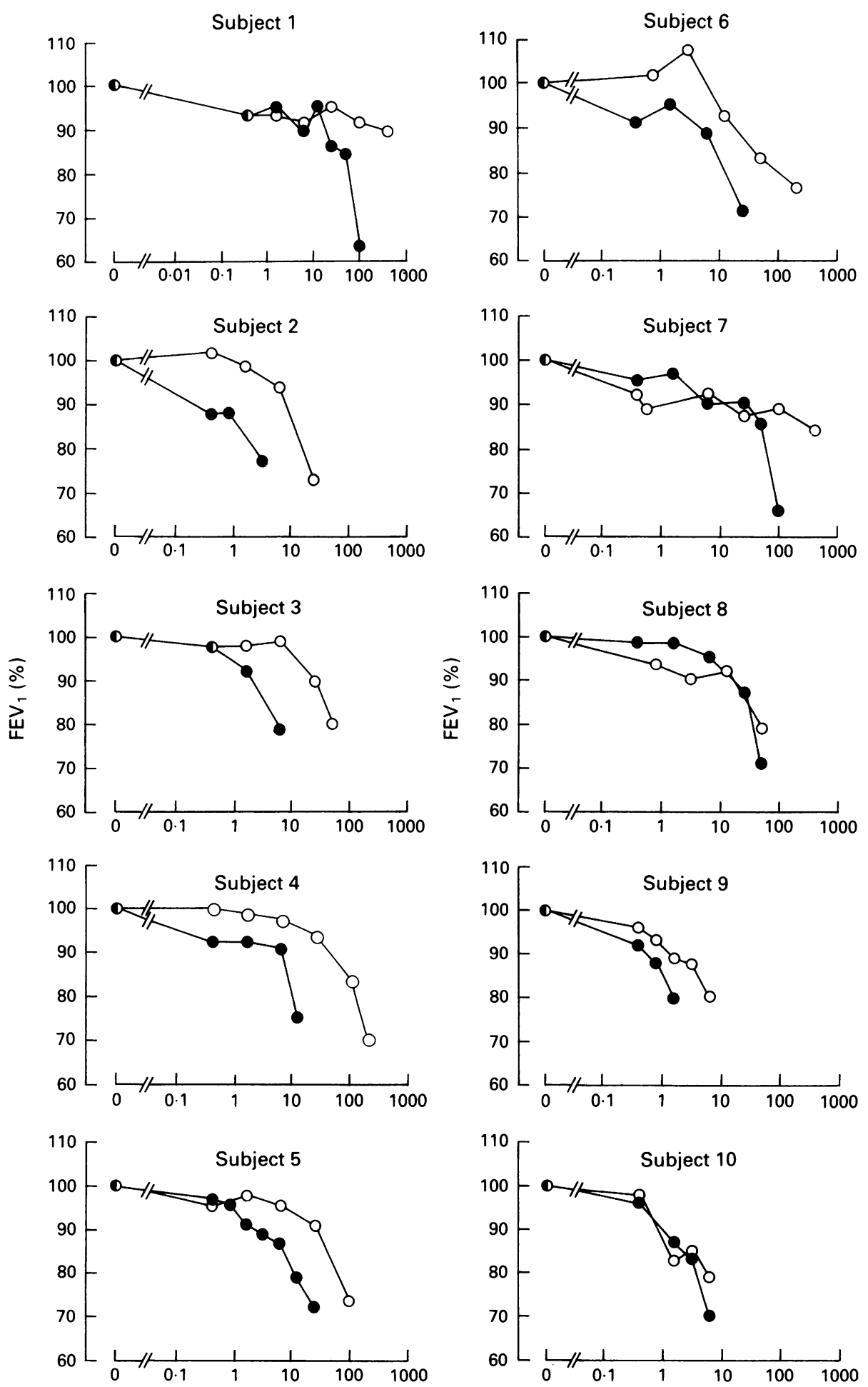

$\operatorname{AMP}(\mathrm{mg} / \mathrm{ml})$

Figure 1 Bronchoconstrictor response to AMP in all 10 subjects following pretreatment with frusemide $(O)$ and placebo (O)

imately fivefold protection against bronchoconstriction induced by both AMP and bradykinin. Since these agonists are considered to produce bronchoconstriction by differing mechanisms - bradykinin involving sensory nerve stimulation and tachykinin release, and AMP augmenting mast cell mediator release and, to a lesser extent, via neural stimulation the mechanism of protection afforded by frusemide is puzzling.

The lack of correlation between histamine and either bradykinin or AMP bronchial reac- tivities supports indirect mechanism(s) of action for bradykinin and AMP. Three subjects (nos 2,3, and 8 ) have shown more than a doubling concentration difference in $\mathrm{PC}_{20}$ for AMP on baseline and placebo days (table 2). We have previously shown, however, that coefficients of repeatability were within single doubling concentrations for AMP and bradykinin. ${ }^{619}$

Since the original description by Bianco et al of the inhibitory effect of inhaled but not oral frusemide against exercise-induced asthma, ${ }^{3}$ 

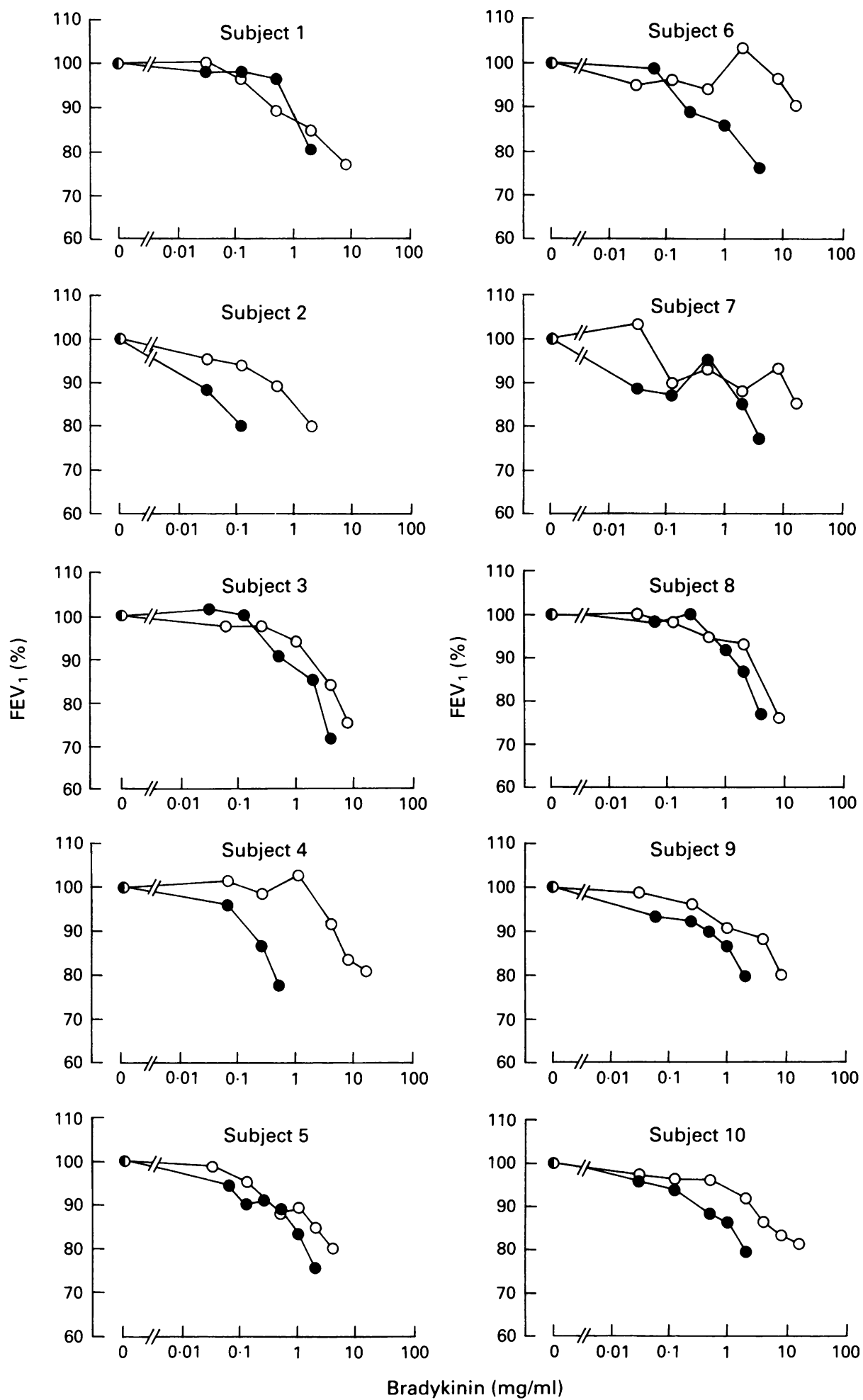

Figure 2 Bronchoconstrictor response to bradykinin in all 10 subjects following pretreatment with frusemide $(\bigcirc)$ and placebo $(\mathbf{O})$.

further studies have shown that it affords little or no protection against histamine-induced bronchoconstriction ${ }^{7}$ and only minor protection against methacholine. ${ }^{6}$ In providing protection against different "indirect" stimuli such as allergen, ${ }^{1}$ fog, ${ }^{2}$ exercise, ${ }^{3}$ cold air, ${ }^{4}$ sodium metabisulphite, ${ }^{5}$ AMP, ${ }^{67}$ and now bradykinin, however, the inhibitory effect must embrace a mechanism or mechanisms common to all these stimuli.

Frusemide is known to produce some of its effect in the kidney by the secondary produc- tion of endogenous prostanoids, ${ }^{2223}$ and in bovine tracheal mucosa it produces $\mathrm{PGE}_{2}{ }^{9}$ Furthermore, a recent study has shown that indomethacin reduced the protective effect of frusemide against exercise-induced asthma, ${ }^{24}$ suggesting release of prostaglandins such as $\mathrm{PGE}_{2}$ and $\mathrm{PGI}_{2}$ which are both potent functional antagonists. Both human airways and pulmonary vascular endothelial cells are rich sources of $\mathrm{PGI}_{2}$ and $\mathrm{PGE}_{2} \cdot{ }^{2526}$ In asthma inhaled $\mathrm{PGI}_{2}$ has been shown to afford short term protection against stimuli such as exer- 
cise, ${ }^{27}$ fog, ${ }^{27}$ and $\mathrm{PGD}_{2}{ }^{28}$ in the absence of any consistent bronchodilator effect. Similarly, inhaled $\mathrm{PGE}_{2}$ protects against the contractile effect of sodium metabisulphite and methacholine in asthma. ${ }^{29}$ Another loop diuretic, bumetanide, which is also known to induce the generation of prostanoids and act via the $\mathrm{Na}$ $\mathrm{K}-\mathrm{Cl}$ cotransporter mechanism in renal tubules, has not been shown to afford protection against AMP. ${ }^{7}$ This indicates that the airway effects of frusemide may be mediated through pathways independent of its shared properties with bumetanide. However, the lack of effect of bumetanide might also have been due to its pharmacokinetic properties.

The bronchoconstrictor actions of AMP and bradykinin are inhibited by disodium cromoglycate and nedocromil sodium ${ }^{1830}$ and attenuated by anticholinergic agents, ${ }^{13} 31-33$ suggesting that excitation of neural pathways may underlie these responses. Furthermore, FK 224, a neurokinin 1 antagonist, has been shown to afford protection against bradykinin-induced bronchoconstriction in asthma ${ }^{17}$ Mast cell release of histamine plays no significant part in bradykinin-induced bronchoconstriction in asthma. ${ }^{19}$ While antihistamines have been shown to afford protection against AMPinduced bronchoconstriction, ${ }^{3134}$ this protection was incomplete and additional pathways are likely to be involved. One possibility is that vagal reflexes may contribute directly to the bronchoconstriction induced by inhaled purines in asthma, as suggested by Pauwels et al. ${ }^{35}$ Furthermore, Polosa et al have shown that inhaled ipratropium bromide affords a significant 2.5 fold protection against AMPinduced bronchoconstriction in asthma. ${ }^{31}$ However, the exact stimulus prompting the vagal reflex activation remains to be clarified. Possibilities include a direct effect of purines in the stimulation of cholinergic reflexes, or indirect activation through the release of mast cell mediators such as histamine and prostaglandins. In support of the ability of histamine to influence vagal airway tone, both atropine and inhaled hexamethonium bromide have been shown to be effective inhibitors of histamine-induced bronchoconstriction through cholinergic and ganglionic blockade respectively. ${ }^{36} 37$

Peachell et al have shown that, in immunologically activated human lung mast cells, adenosine not only enhances histamine release but also potentiates production of prostanoids. $^{38}$ Furthermore, in asthma, cyclooxygenase blockade has been shown to inhibit the bronchoconstrictor response provoked by inhaled purines. ${ }^{3940}$ As the effects of prostanoids on airway calibre are known to be mediated in part by vagal reflexes, ${ }^{41}$ it is possible that adenosine-induced production of prostanoids from mast cells contributes to bronchoconstriction via cholinergic pathways. Some evidence has accumulated to indicate that inhaled frusemide might alter neural activity in the airways. In healthy subjects inhaled frusemide inhibits cough responses induced by low chloride aerosols. ${ }^{11}$ Further evidence derives from the observation that both frusemide and bumetanide inhibit the airway smooth muscle contraction induced by stimulation of non-cholinergic non-adrenergic nerves independent of cyclooxygenase production. ${ }^{12}$

Our observations of a similar degree of protection produced by frusemide against the airways response to inhaled AMP and bradykinin, and the finding of a significant correlation between the degree of protection against both stimuli, suggest that inhaled frusemide may act on a common mechanism. Since many of the other "indirect" stimuli also involve neural reflexes to a greater or lesser extent, this seems the most likely component of the bronchoconstrictor response that is frusemide sensitive.

This study was supported by a grant from the Ferring Peptide Research Partnership, Malmo, Sweden. The authors thank Mr J Thom of the Pharmacy Department, Southampton General Hospital for preparing and randomising the frusemide and placebo solutions.

1 Bianco S, Pieroni MG, Refini RM, Rottoli L, Sestini P. Protective effect of inhaled frusemide on allergen-induced Protective effect of inhaled frusemide on allergen-induced early and late

2 Robuschi M, Gambard G, Spagnotto S, Vaghi A, Bianco S. Inhaled frusemide is highly effective in preventing ultrasonically nebulised water induced bronchoconstriction. Pulmon Pharmacol 1989;1:187-91.

3 Bianco S, Vaghi A, Robuschi M. Pasargiklian M. Prevention of exercise-induced bronchoconstriction by inhaled frusemide. Lancet 1988;ii:252-5.

4 Grubbe RE, Hopp R, Dave NK, Brennan B, Bewtra A, Townley R. Effect of inhaled furosemide on the bronchial response to methacholine and cold-air hyperventilation response to methacholine and cold-air hyperventilat
challenges. F Allergy Clin Immunol 1990;85:881-4.

challenges. F Allergy Clin Immunol 1990;85:881-4.
5 Nichol GM, Alton EWFW, Nix A, Geddes DM, Chung KF, Barnes PJ. Effect of inhaled furosemide on meta$\mathrm{KF}$, Barnes PJ. Effect of inhaled furosemide on meta-
bisulfite and methacholine-induced bronchoconstriction and nasal potential difference in asthmatic subjects. $\mathrm{Am}$ Rev Respir Dis 1990;142:576-80.

6 Polosa R, Lau LCK, Holgate ST. Inhibition of adenosine 5 -monophosphate (AMP) and methacholine-induced bronchoconstriction in asthma by inhaled frusemide. Eur Respir $\mathcal{f}$ 1990;3:665-72.

7 O'Connor BJ, Chung KF, Chen-Worsdell YM, Fuller RW, Barnes PJ. Effect of inhaled furosemide and bumetanide on adenosine $5^{\prime}$-monophosphate- and sodium metabisulAm Rev Respir Dis 1991;143:1329-33.

8 Scherer B, Weber PC. Time-dependent changes in prostaglandin excretion in response to frusemide in man. Clin glandin excretion in
Sci $1979 ; 56: 77-81$.

9 Pavord I, Knox AJ, Cole A, Tattersfield AE. Effect of frusemide on release of prostaglandin $E_{2}$ by bovine tracheal mucosa. Thorax 1991;46:751P.

10 Temple DM, Wei HE, Anderson SD. Inhibition of furosemide of inflammatory mediators from lung fragments. $N$ Eng $\mathcal{F}$ Med 1990;324:131 (letter).

11 Ventrasca PG, Nichol GM, Barnes PJ, Chung KF. Inhaled furosemide inhibits cough induced by low chloride content solutions but not by capsaicin. Am Rev Respir Dis 1990;142:143-6.

12 Elwood W, Lotvall JO, Barnes PJ, Chung KF. Loop diuretics inhibit cholinergic and non-cholinergic nerves in guinea pig airways. Am Rev Respir Dis 1991;143:1340-4.

13 Rajakulasingam K, Polosa R, Church MK, Holgate ST, 22:734-40.

14 Polosa R, Holgate ST. Comparative airway response to inhaled bradykinin, kallidin and [des-arg']-bradykinin in normal and asthmatic subjects. Am Rev Respir Dis 1990; 142:1367-71.

15 Fuller RW, Dixon CMS, Cuss FMC, Barnes PJ. Bradykinin-induced bronchoconstriction in humans: mode of action. Am Rev Respir Dis 1987;135:176-80.

16 Ichinose M, Belvisi MG, Barnes PJ. Bradykinin-induced bronchoconstriction in guinea pig in vivo: role of neural mechanisms. F Pharmacol Exp Ther 1990;253:594-9.

17 Ichinose $M$, Nakajima N, Takahashi T, Yamanuchi $H$ Inoue $\mathrm{H}$, Takishima $\mathrm{T}$. Protection against bradykinininduced bronchoconstriction in asthmatic patients by neurokinin receptor antagonist. Lancet 1992;340:1248-51.

18 Dixon CMS, Barnes PJ. Bradykinin-induced bronchoconstriction: inhibition by nedocromil sodium and sodium striction: inhibition by nedocromil sodium and sodit

19 Polosa R, Phillips GD, Lai CKW, Holgate ST. Contribution of histamine and prostanoids to bronchoconstriction provoked by inhalec

20 Newman SP, Pellow PGD, Clarke SW. Droplet size distributions of nebulised aerosols for inhalation therapy. Clin Phys Physiol Meas 1986;7:139-46. 
21 Chai H, Farr RS, Froehlich LA, Mathison DA, McLean JA, Rosenthal RR, et al. Standardization of bronchial inhalation chalenge procedures. $\mathcal{F}$ Allergy Clin Immunol 1975;56:323-7.

22 Struyker-Boudier HAJ, Smits JFM, Kleinjans JCS, Van Essen H. Haemodynamic actions of diuretic agents. Clin Essen H. Haemodynamic action

23 Bourland WA, Day DK, Williamson HE. The role of the kidney in the early nondiuretic action of furosemide to reduce elevated left atrial pressure in the hypervolaemic dog. F Pharmacol Exp Ther 1977;202:221-9.

24 Pavord I, Wisniewski A, Tattersfield AE. Inhaled frusemide and exercise-induced asthma. Evidence of a role for inhibitory prostanoids. Thorax 1992;47:797-800.

25 Schulman ES, Adkinson NF Jr, Newball HH. Cyclooxygenase metabolites in human lung anaphylaxis. Airways vs parenchyma. 7 Appl Physiol Respir Environ Exercise Physiol 1982;53:589-95.

26 Szceklik A, Gryglewski RJ, Nizankowski R, Musial J, Pieton R, Mruk J. Circulatory and antiplatelet effects of intravenous prostacyclin in healthy man. Pharmacol intravenous prostacyclin in healt

27 Bianco S, Robuschi M, Ceserani R, Gandolfio C. Effects of prostacyclin on aspecifically and specifically induced bronchoconstriction in asthmatic subjects. Eur $\mathcal{f}$ Respir Dis 1980;106(Suppl):81-7.

28 Hardy CC, Bradding P, Robinson C, Holgate ST. Bronchoconstrictor and antibronchoconstrictor properties of inhaled prostacyclin in asthma. $\mathcal{F}$ Appl Physiol 1988;64: 1567-74.

29 Pavord ID, Wisniewski A, Mathur R, Wahedna I, Knox $\mathrm{AJ}$, Tattersfield AE. Effect of inhaled prostaglandin $\mathrm{E}_{2}$ on bronchial reactivity to sodium metabisulfite and methacholine in patients with asthma. Thorax 1991;46:633-7.

30 Phillips GD, Scott VL, Richards R, Holgate ST. Effect of nedocromil sodium and sodium cromoglycate against nedocromil sodium and sodium cromoglycate against
bronchoconstriction induced by inhaled adenosine $5^{\prime}$ bronchoconstriction induced by inhaled a
monophosphate. Eur Respir 7 1989;2:210-7.

31 Polosa R, Phillips GD, Rajakulasingam K, Holgate ST The effect of inhaled ipratropium bromide alone and in combination with oral terfenadine on bronchoconstriction provoked by adenosine $5^{\prime}$-monophosphate and histamine in asthma. 7 Allergy Clin Immunol 1991;87:939-47.

32 Mann JS, Cushley MJ, Holgate ST. Adenosine-induced bronchoconstriction in asthma: role of parasympathetic stimulation and adrenergic inhibition. Am Rev Respir Dis 1985;132:1-6.

33 Okayama $M$, Ma J-Y, Hataoka I, Kimura K, Miura M, Iijima $\mathrm{H}$, et al. Role of vagal nerve activity on adenosineinduced bronchoconstriction in asthma. Am Rev Respir Dis 1986; 133 (Suppl): A93.

34 Phillips GD, Rafferty P, Beasley CRW, Holgate ST. The effect of oral terfenadine on the bronchoconstrictor response to inhaled histamine and adenosine 5 '-monophosphate in non-atopic asthma. Thorax 1987; 42: 939-45.

35 Pauwels RA, Van der Straeten ME. An animal model for adenosine-induced bronchoconstriction. Am Rev Respir Dis 1987; 136: 374-8.

36 Sheppard D, Epstein J, Skoogh BE, Bethel RA, Nadel JA Boushey HA. Variable inhibition of histamine-induced bronchoconstriction by atropine in subjects with asthma. f Allergy Clin Immunol 1984; 73: 82-7.

37 Holtzman MJ, Sheller JR, DiMeo M, Nadel JA, Boushey HA. Effect of ganglionic blockade on bronchial reactivity HA. Effect of ganglionic blockade on bronchial reactivity

38 Peachell PT, Columbo M, Kagey-Sobotka A, Lichtenstein LM, Marone G. Adenosine potentiates mediator release from human lung mast cells. Am Rev Respir Dis 1988; 138: 1143-51

39 Phillips GD, Holgate ST. The effect of oral terfenadine alone and in combination with flurbiprofen on the bronchoconstrictor response to inhaled adenosine 5'-monophosphate in non-atopic asthma. Am Rev Respir Dis 1989; 139: 463-9.

40 Crimi N, Palermo F, Polosa R, Oliveri R, Maccarrone C, Palermo B, et al. Effect of indomethacin on adenosineinduced bronchoconstriction. $\mathcal{f}$ Allergy Clin Immunol 1989; 83: 921-5.

41 Beasley R, Varley J, Robinson C, Holgate ST. Cholinergicmediated bronchoconstriction induced by prostaglandin $\mathrm{D}_{2}$, its initial metabolite 9 alpha, 11 beta-PGF ${ }_{2}$ and $\mathrm{PGF}_{2}$ alpha in asthma. Am Rev Respir Dis 1987; 136: 1140-4. 